\title{
CRIANDO E USANDO HIPERMÍDIA NA EDUCAÇÃO
}

Ministrante:

Prof. Mestre Paulo Roberto Bortoli

(Especialista em Informática na Educação)

e-mail: prbortoli_educ@terra.com.br

\section{Tópicos}

I - $\quad$ Síntese sobre a hipermídia na educação.

II - $\quad$ Sistemas de Autoria

III - Utilizando um Sistema de Autoria

I -

Multimídia

Hipermídia

Hipertexto

Hipermídia e Educação

II-

Sistema Autoria

Metáfora da Pasta

Uso da Pasta

Multimídia

Objetos e recursos

Orientação a Objetos

III-

Modelo de Dados de um Sistema de Autoria

$>$ Aplicação

$>$ Pasta

$>$ Página

$>$ Objetos

A Janela de trabalho de um Sistema de Autoria

Tipos de páginas:

Comum

Base

V. $2 \mathrm{~N}^{\circ} 1$, Março, 2004 


\section{Barra de Menu}

$>$ Pasta

Nova

Abrir

Fechar

Salvar

Salvar como

Atributos

Nível de acesso

Agrupar recursos

\section{Editar}

\section{Cortar}

Copiar

Colar

\section{$>$ Página}

Nova

Atributos

\section{Objetos}

Novo

$>$ Aplicação

Nova

Abrir

Barra de Ícones

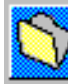

Salvar Pasta

$\mathrm{CP}$

... Abrir Pasta

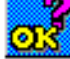

Testar

35

Página Seguinte/Anterior

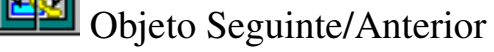

อОTล้ก

—. Objeto Botão

- $\quad$ Script

2 


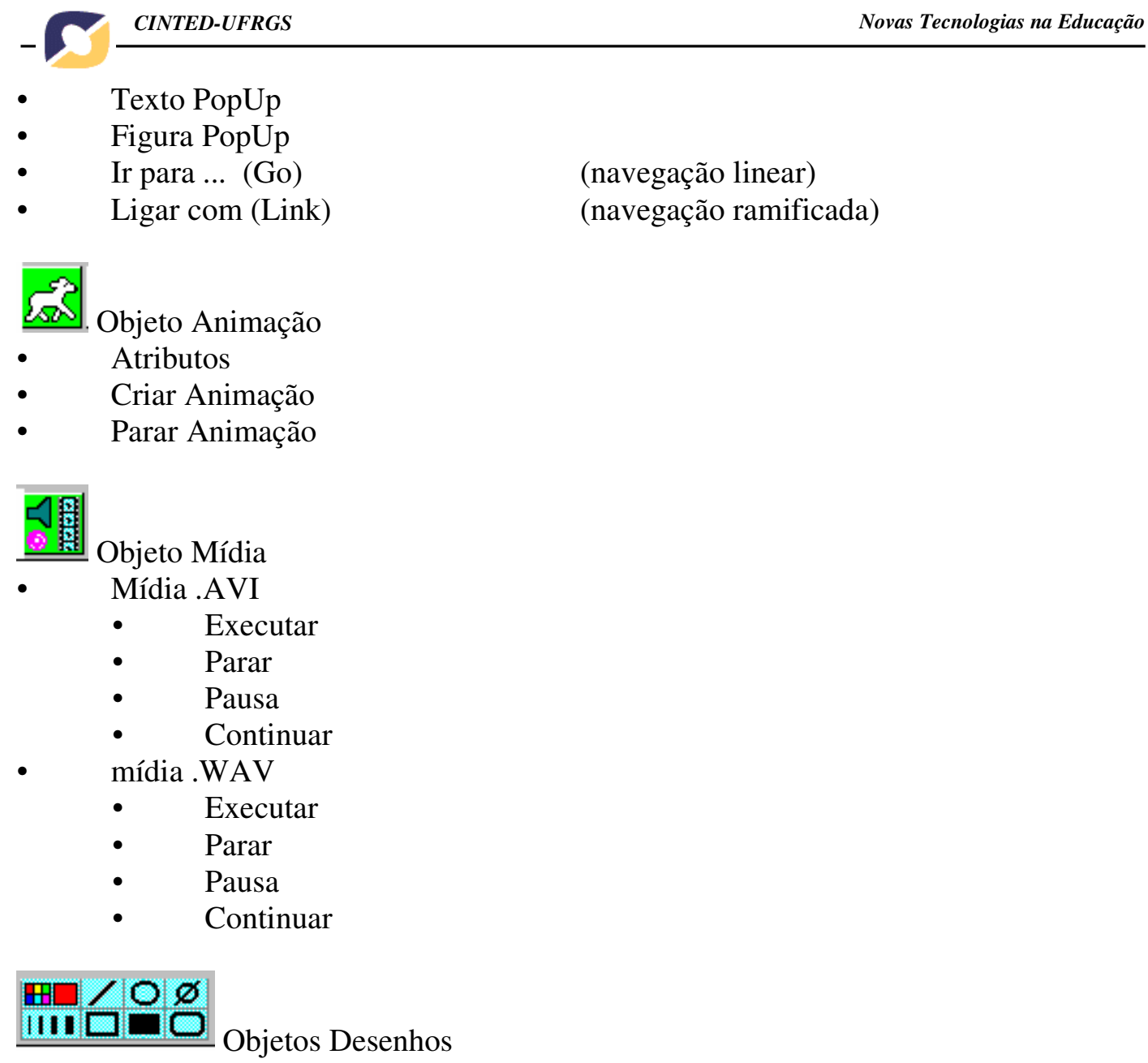

\section{- $\quad$ Publico alvo}

Professores, psicólogos, pedagogos e profissionais de áreas afins com conhecimento básico do Windows.

\section{- $\quad$ Número de participantes}

10 a 12 (preferenciamente um por micro)

\section{- Recursos necessários}

Uma estação por participante (considerando uma para cada inscrito)

Sistema operacional Windows 9X, ME, XP ou NT

Windows Media Player instalado

Hardware

CR-ROM

Placa de som

$32 \mathrm{MB}$ de RAM

2 MB memória de vídeo

3 MB de HD livre

Mouse

Projetor de Multimídia

Obs.: O sistema de autoria será instalado apenas para o evento, devendo ser excluído imediatamente após seu termino. 